\title{
DEVELOPMENT OF AGRICULTURAL TRANSPORT ROAD NETWORK IN LAND CONSOLIDATION WORKS
}

\author{
Jaroslaw Taszakowski, Jaroslaw Janus,Agnieszka Glowacka, PiotrBozek \\ University of Agriculture in Krakow, Poland \\ j.taszakowski@ur.krakow.pl,j.janus@ur.krakow.pl, \\ a.glowacka@ur.krakow.pl,p.bozek@ur.krakow.pl
}

\begin{abstract}
Consolidation and post-consolidation development-related investments are an opportunity to improve living and working conditions of rural residents. Land consolidation is practically the only comprehensive tool to improve the shape of the transport network in the areas covered by this process. Moreover, improving the quality of the transport network is in fact one of the main objectives of land consolidation works. In Poland, consolidation is possible owing to the EU funds RDP 2014-2020, which provide for the possibility of financing among other things, the construction of new roads, reconstruction of the existing roads and elimination of unnecessary agricultural transport roads. The aim of this paper is to analyse documentation in the form of assumptions for a land consolidation project enclosed to the RDP 2014-2020 grant application, as the basis for determining the activities and investments of post-consolidation development, related to agricultural transport road network and demonstrate financial needs in this area. The detailed study involved 9 villages in the Malopolskie Voivodeship, which applied for the EU grants for land consolidation in the current financial perspective. The paper specifies the existing state of the analysed villages as regards the agricultural road network and plots without an access to a public road defining an index for plots without road access. The study presents also types of investments under post-consolidation development regarding the development of the agricultural transport road network. As a consequence, it specifies the density indicator of agricultural transport road network before consolidation and the anticipated growth after its implementation planed in the assumptions for a land consolidation project.
\end{abstract}

Keywords: land consolidation, agricultural management, agricultural road network.

\section{Introduction}

Land consolidation is a fundamental instrument for agricultural management $[1 ; 2]$. It facilitates comprehensive changes in the agricultural, social, and ecological domains [3]. Land consolidation and post-consolidation development-related investment projects are an opportunity to improve living and working conditions in rural areas but mostly improving farming conditions. The functionality of rural areas depends on the correctness of agricultural transport road network [4]. A faulty network is one of the primary reasons for redevelopment of spatial structure by way of land consolidation [5].

Land consolidation results in reorganisation of holdings and helps improve the land layout [6;7], which depends on the surface area of the holding, number of plots, surface are of the plots, distance from plots to the house, and the plot perimeter. Improvement of agricultural transport road networks and their quality [8] is also one of the key conditions of agricultural management.

In Poland, land consolidation is possible owing to the RDP 2014-2020 EU funds [9]. They provide means for construction of new roads, reconstruction of the existing roads, and decommissioning of redundant agricultural transport roads.

Construction or reconstruction of access roads to agricultural or forest land and buildings of individual participants in the land consolidation process takes place during post-consolidation development [9], which is an integral part of land consolidation. The specific nature of agricultural transport influences design solutions for agricultural roads. They should be designed to provide convenient, the shortest possible access to agricultural land (each plot) from the house. The impact of costs of transport from the house to the holding has been studied extensively [10-12].

The goal of this paper is to analyse documentation in the form of assumptions for a land consolidation project enclosed to the RDP 2014-2020 grant application for the works as the basis to determine activities under post-consolidation development as regards the agricultural transport road network and to demonstrate the financial effort necessary.

Based on quantitative data of the agricultural transport road network before land consolidation and its planned changes as a result of land consolidation and post-consolidation development, the density index of the current agricultural transport road, the density index of the planned agricultural transport road, and their percentage shift indicator were calculated. 
The presented analyses are the support to answer the question if the agricultural transport road network development, achieved as a result of land consolidation, always be expressed through increase of the density index of the agricultural transport road. Moreover, improving agricultural management conditions that are the primary goal of land consolidation is always associated with an increase in the number of roads in the proposed consolidation area.

\section{Materials and methods}

The detailed study involved 9 villages in the Małopolskie Voivodeship, which applied for the EU grants for land consolidation in the current financial perspective. The analysis involved materials from documentation in the form of assumptions for a land consolidation project enclosed to the RDP 20142020 grant application for the following objects: Krzeczow, Wysoka, Strzelce Wielkie, Uście Solne, Czubrowice, Lusina, Marcinkowice, Popędzyna, and Dolany. The location of the study area is shown in Figure 1.

The paper describes the current condition of the analysed villages as regards the agricultural transport road network, plots without access to a public road, and types of post-consolidation development investments in terms of development of the agricultural transport road network.

As a consequence, a density index of the agricultural transport road network before consolidation (1) and density index of the planned agricultural transport road (2) were calculated. At the end, the percentage shift index (3) was calculated.

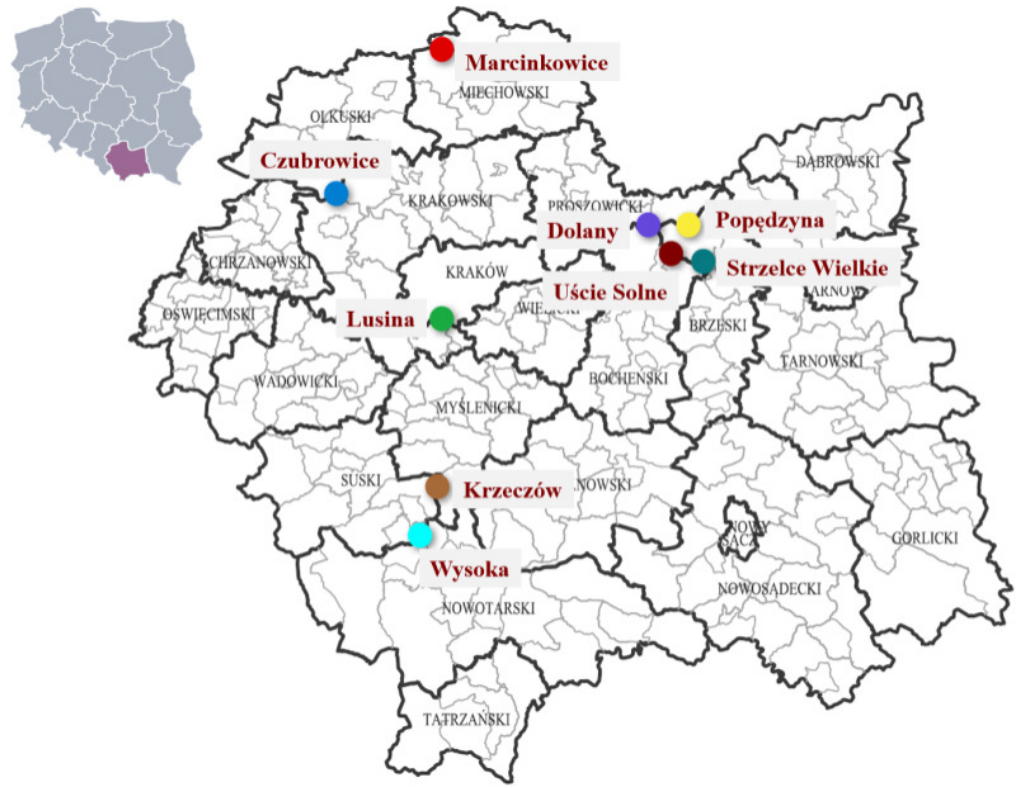

Fig. 1. Location of study objects in Malopolska Voivodeship

$$
I_{d e}=\frac{100 \times L_{e s t}}{A_{F}} \text {,(1) } I_{d d}=\frac{100 \times L_{d s t}}{A_{F}} \text {,(2) } I_{C}=\frac{I_{d d}-I_{d e}}{A_{F}} \times 100 \% \text {, (3) }
$$

where $I_{d e}$ - density index of the current agricultural transport road, $\mathrm{km} \cdot(100 \mathrm{ha})^{-1} A_{F}$;

$I_{d d}$ - density index of the planned agricultural transport road, $\mathrm{km} \cdot(100 \mathrm{ha})^{-1} A_{F}$;

$L_{e s t}$ - length of the current agricultural transport road, km;

$L_{d s t}$ - length of the planned agricultural transport road, km;

$A_{F}$ - area of farmland, ha;

$I_{C}$ - percentage shift indicator.

The fundamental issue for the preparation of assumptions for land consolidation projects is detailed and in-depth analysis of the current state of the whole area included in the project. The analysis involves the land use structure, fragmentation, land holding, existing road and drainage network, and objects valuable due to their environmental qualities. Road survey and analysis of the number of plots without a legal access to a road are the basis for preparing changes in a road network. Table 1 shows the results of studies on the scale of the lack of legal access to a public road, which was 
presented for selected objects in a graphic form in Figure 2. According to the studies, up to $50 \%$ of plots have no legal access to a public road in some precincts.

\section{Analysis of lack of access to a public road}

Table 1

\begin{tabular}{|c|c|c|c|c|c|c|c|}
\hline \multicolumn{8}{|c|}{ Plots without road access - analysis of the current situation } \\
\hline Municipality & Village & 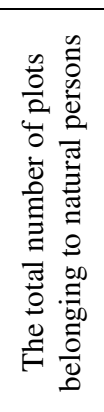 & 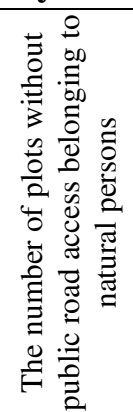 & 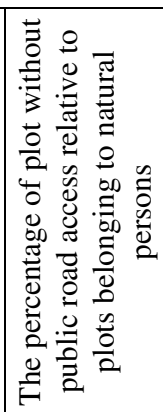 & 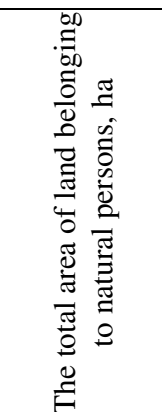 & 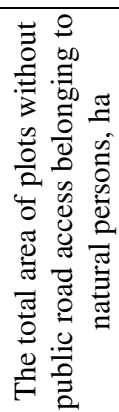 & 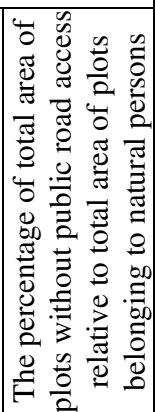 \\
\hline Lubień & Krzeczów & 7803 & 4553 & 58.3 & 957.3670 & 567.71 & 59.3 \\
\hline Jordanów & Wysoka & 4181 & 1488 & 35.6 & 831.4090 & 207.02 & 24.9 \\
\hline Szczurowa & Strzelce Wielkie & 2280 & 873 & 38.3 & 954.1252 & 250.02 & 26.2 \\
\hline Szczurowa & Uście Solne & 2521 & 411 & 16.3 & 816.7499 & 94.61 & 11.6 \\
\hline $\begin{array}{l}\text { Jerzmanowice- } \\
\text { Przeginia }\end{array}$ & Czubrowice & 1781 & 217 & 12.2 & 809.2857 & 64.85 & 8.0 \\
\hline Mogilany & Lusina & 1350 & 346 & 25.6 & 358.3179 & 92.43 & 25.8 \\
\hline Charsznica & Marcinkowice & 1015 & 191 & 18.8 & 404.5185 & 35.5 & 8.8 \\
\hline Szczurowa & Popędzyna & 423 & 154 & 36.4 & 172.5028 & 57.7 & 33.4 \\
\hline Koszyce & Dolany & 160 & 3 & 1.9 & 139.6522 & 5.23 & 3.7 \\
\hline
\end{tabular}

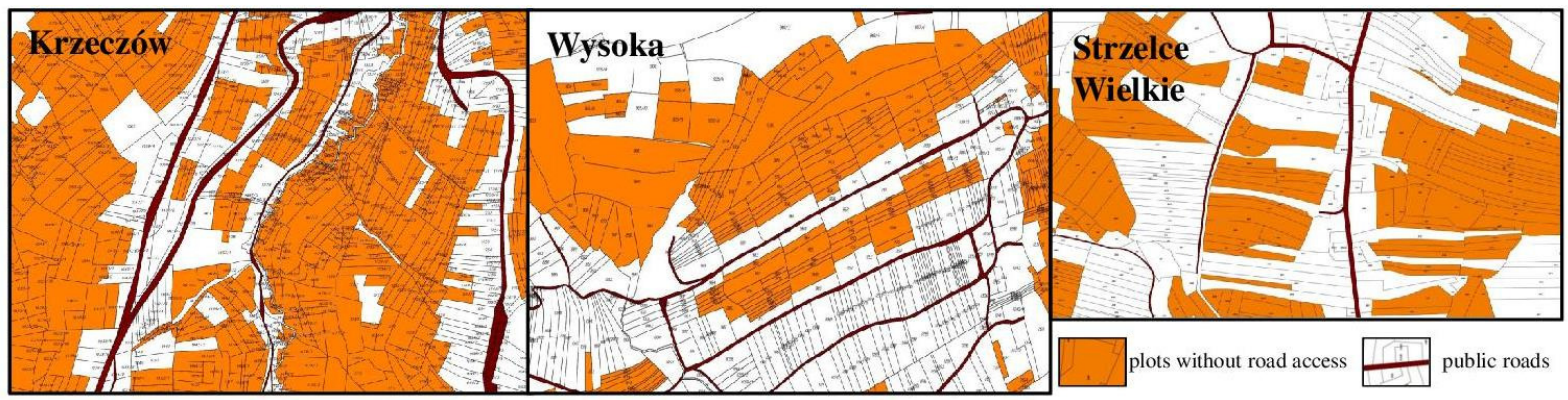

Fig. 2. Examples of complex plots without legal access to a public road

The concept for changes in an agricultural transport road system is based on an analysis of the roads at the stage of existing state survey. Its graphic form together with an analysis of plots without a legal access to a public road is in turn the fundamental method for road network development. Relevant studies are presented in Table 2. Figure 3 shows photographs of agricultural transport roads taken during a field survey.

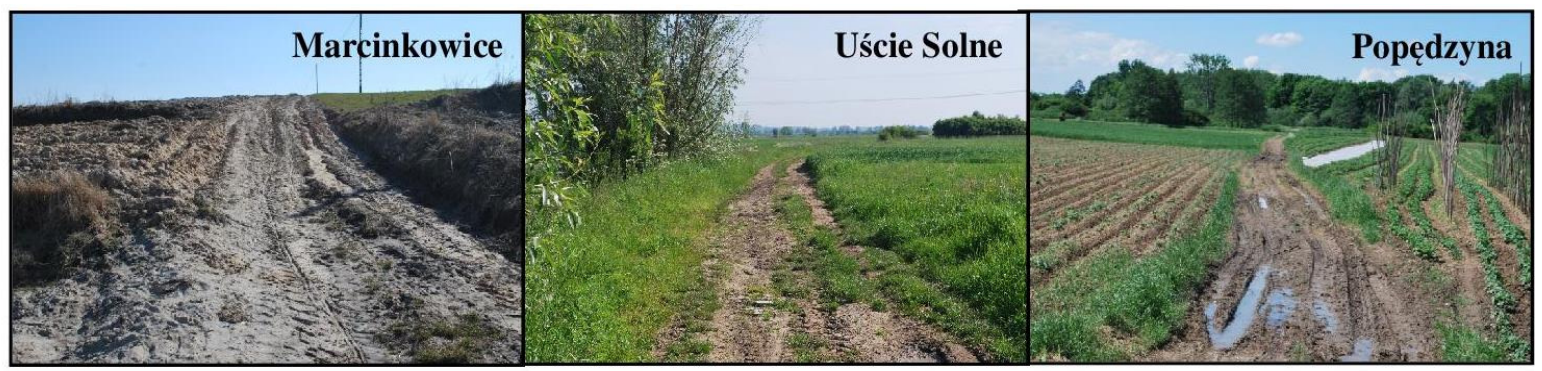

Fig. 3. Agricultural transport roads in need of reconstruction 
Analysis of the current agricultural transport road network

Table 2

\begin{tabular}{|c|c|c|c|c|c|c|c|c|}
\hline \multirow{3}{*}{ Municipality } & \multirow{3}{*}{ Village } & \multicolumn{7}{|c|}{ Roads } \\
\hline & & \multicolumn{2}{|c|}{$\begin{array}{l}\text { Bituminous } \\
\text { pavement }\end{array}$} & \multicolumn{2}{|c|}{$\begin{array}{c}\text { Crushedstone } \\
\text { pavement }\end{array}$} & \multicolumn{2}{|c|}{ Unpaved } & \multirow{2}{*}{$\begin{array}{c}\text { Total } \\
\mathrm{km} \\
\end{array}$} \\
\hline & & $\mathrm{km}$ & $\%$ & $\mathrm{~km}$ & $\%$ & $\mathrm{~km}$ & $\%$ & \\
\hline Lubień & Krzeczów & 11.815 & 24.81 & 6.715 & 7.95 & 29.117 & 67.24 & 47.647 \\
\hline Jordanów & Wysoka & 16.495 & 27.64 & 8.368 & 14.02 & 34.814 & 58.34 & 59.677 \\
\hline Szczurowa & Strzelce Wielkie & 19.119 & 32.13 & 11.63 & 19.54 & 28.758 & 48.33 & 59.507 \\
\hline Szczurowa & Uście Solne & 16.263 & 53.49 & 6.883 & 22.65 & 7.255 & 23.86 & 30.401 \\
\hline $\begin{array}{l}\text { Jerzmanowice- } \\
\text { Przeginia }\end{array}$ & Czubrowice & 8.889 & 25.78 & 4.338 & 12.58 & 21.252 & 61.64 & 34.479 \\
\hline Mogilany & Lusina & 12.274 & 40.82 & 9.314 & 30.98 & 8.479 & 28.2 & 30.067 \\
\hline Charsznica & Marcinkowice & 4.521 & 23.73 & 2.677 & 14.05 & 11.854 & 62.22 & 19.052 \\
\hline Szczurowa & Popędzyna & 2.354 & 14.17 & 4.458 & 26.84 & 9.796 & 58.99 & 16.608 \\
\hline Koszyce & Dolany & 3.197 & 44.17 & 1.386 & 19.15 & 2.655 & 36.68 & 7.238 \\
\hline
\end{tabular}

\section{Results and discussion}

Field survey results and the analysis of plot without a legal access to a public road together with social consultations regarding changes in agricultural transport road network were used to assemble a table showing the development of the agricultural transport road network and the scope of investments under post-consolidation development. As regards agricultural transport road networks, pursuant to the Act on land consolidation and exchange, post-consolidation development includes construction of new roads, alteration of the existing roads, and decommissioning of redundant roads. New and altered roads will be crushed stone or bituminous roads. Pending assumptions to the land consolidation project for the whole territory of the MałopolskieVoivodeship strive to unify all planned investment projects, which is confirmed by the data in Table 3.

Table 3

Changes in the agricultural transport road network

\begin{tabular}{|c|c|c|c|c|c|c|c|c|c|c|}
\hline \multirow{2}{*}{\multicolumn{2}{|c|}{ jects }} & \multicolumn{9}{|c|}{ Municipality/Village } \\
\hline & & 를 & 疍 & 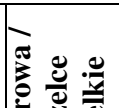 & 范 & 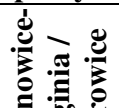 & ฏ。 & ฮั & 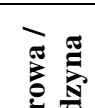 & ¿ \\
\hline $\begin{array}{l}\text { new roads to be constructed - } \\
\text { bituminous pavement }\end{array}$ & $\mathrm{km}$ & - & - & 4.076 & - & 0.369 & - & 0.118 & 0.187 & - \\
\hline $\begin{array}{l}\text { new roads to be constructed - } \\
\text { crushed stone pavement }\end{array}$ & $\mathrm{km}$ & 25.295 & 8.038 & 7.328 & 5.232 & 13.185 & 2.907 & 3.839 & 2.001 & 0.964 \\
\hline $\begin{array}{l}\text { new roads to be constructed - } \\
\text { dirt roads with cellular geogrid }\end{array}$ & $\mathrm{km}$ & - & - & 34.219 & 5.649 & - & 1.476 & 3.105 & 0.371 & 0.527 \\
\hline $\begin{array}{l}\text { New roads to be constructed, } \\
\text { total }\end{array}$ & km & 25.3 & $\mathbf{8 . 0 3 8}$ & 45.623 & 10.88 & 13.554 & 4.383 & 7.062 & 2.559 & 1.491 \\
\hline $\begin{array}{l}\text { existing roads to be } \\
\text { reconstructed - widening and } \\
\text { bituminous pavement }\end{array}$ & $\mathrm{km}$ & - & - & 1.201 & 1.451 & - & - & 2.771 & 1.036 & - \\
\hline $\begin{array}{l}\text { existing roads to be } \\
\text { reconstructed - widening and } \\
\text { crushed stone pavement }\end{array}$ & $\mathrm{km}$ & 31.399 & 19.366 & 3.639 & 12.310 & 19.544 & 5.037 & 10.308 & 1.797 & 2.618 \\
\hline $\begin{array}{l}\text { Existing roads to be } \\
\text { reconstructed, total }\end{array}$ & km & 31.4 & 19.37 & 4.84 & 13.76 & 19.544 & 5.037 & 13.08 & 2.833 & 2.618 \\
\hline $\begin{array}{l}\text { existing roads to be } \\
\text { decommissioned }\end{array}$ & $\mathrm{km}$ & 0.645 & 10.513 & 14.720 & & 2.531 & & 0.622 & 0.371 & 1.250 \\
\hline $\begin{array}{l}\text { Increase in road network } \\
\text { length }\end{array}$ & km & 24.650 & -2.475 & 30.903 & 10.881 & 11.023 & 4.383 & 6.440 & 2.188 & 0.241 \\
\hline
\end{tabular}


The results in Table 3 demonstrate changes in the length of agricultural transport roads. The largest length of new roads $(45.6 \mathrm{~km})$ was planned for the Village of StrzelceWielkie, Szczurowa Municipality, where over $34 \mathrm{~km}$ of dirt roads on cellular geogrid were designed along a dense network of agricultural drainage ditches in order to maintain extensive farming in Natura 2000 areas.The design resulted in over $14 \mathrm{~km}$ of redundant dirt roads being decommissioned.

A specific phenomenon was noted in the Village of Wysoka, Jordanów Municipality (shown in Figure 4) where the total road length decreased after changes in the road network were designed. This resulted from decommissioning of over $10 \mathrm{~km}$ of redundant dirt roads in the area under design. This solution facilitated implementing a rational shape of the road network that determined design complexes in which cadastral plots could be delimited the shapes of which were more convenient for farming, longer and wider, thus providing larger surface areas.

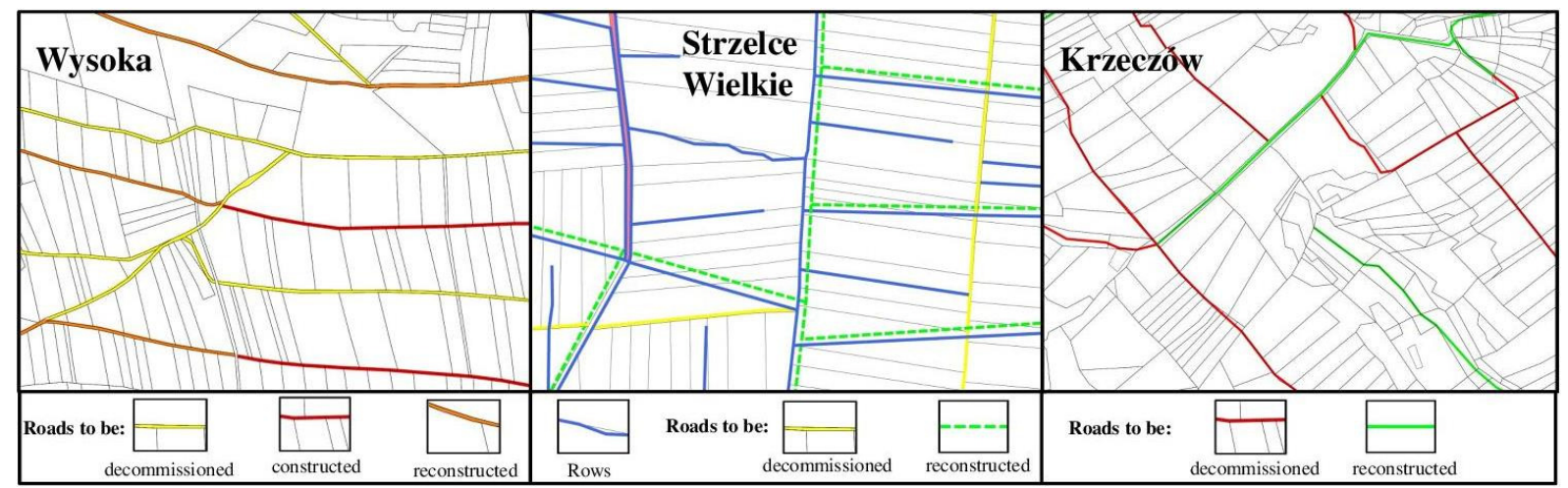

Fig. 4. Examples of changes in the agricultural transport road network

Road density indices were developed for the current and design situation based on the results of the analysis of the as-is condition and changes in the agricultural transport road network; shown in Figure 5. These two values were then used to calculate a percentage agricultural transport road network density shift anticipated as a result of completion of consolidation works. It is shown in Figure 4 (percent values over bars).

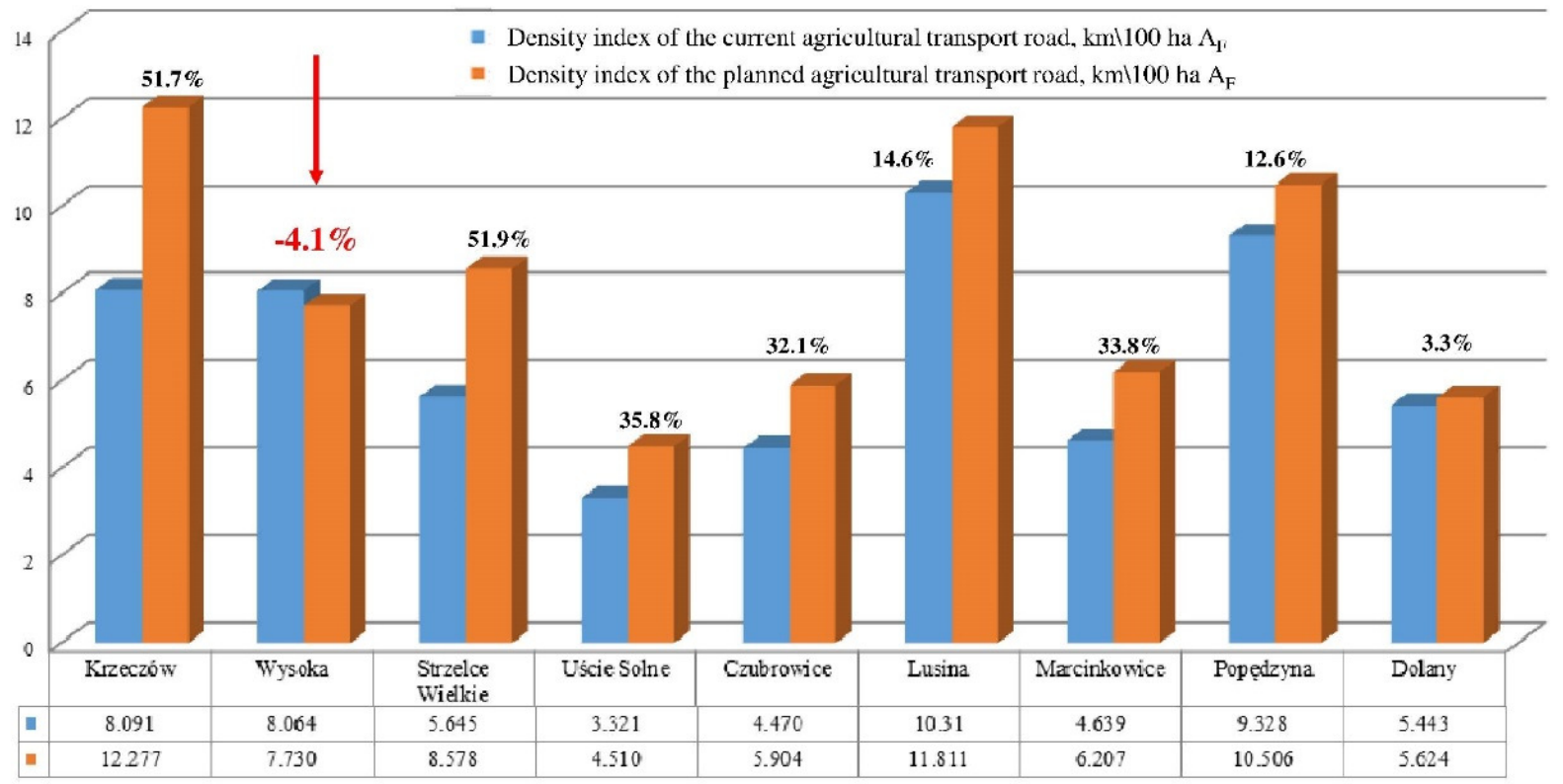

Fig. 5. Comparison of the density index of the agricultural transport road network and the percentage shift indicator

The presented calculations of the percentage shift indicator in research objects point to its considerable variability.It should be emphasized that the land consolidation works in all villages were prepared with particular attention to public participation at this stage and with attention to achieving 
the highest possible results in terms of improving the economic conditions of agriculture, whichthe basis of is a well-shaped road network. In StrzelceWielkie and Krzeczów villages, the highest percentage shift indicator is noticeable, so most roads were designed there. In contrast, in Wysoka village, the percentage shift indicator in the road network is negative. It proves that in the land consolidation project over $4 \%$ of the length of the roads will be decommissioned. As a result of this procedure, the design complexes will be created to allow the creation of new plots with much better parameters. It proves that the negative change rate in the road network also proves its development, by creating a rational, efficient and economic road network. The presented studies have shown that improving of agricultural management conditions as a primary goal of land consolidation does not always entail an increase in the number of roads in the designed area.

\section{Conclusions}

1. The paper presents quantitative studies of agricultural transport road networks in areas under the planned land consolidation in Małopolska in the current financial programme period under the Rural Development Programme 2014-2020.

2. Juxtaposition of the scale of occurrence of plots without access to a public road with a quantitative and qualitative division of a road network by the current condition is the basis for any design works aimed at rational planning of development of agricultural transport roads in consolidated areas that not only impact the development of agriculture, but also affect the general improvement of living and working conditions in rural areas.

3. Presentation of the results of studies using the road network density indices and the percentage road network density shift index provides a great tool for assessing the need of development (changes) of a road network based on the current situation, and on the other hand, gives factual basis for assessing land consolidation effectiveness as regards road network development.

4. The road network density shift index is positive in almost all presented study objects. In one object (Wysoka, Jordanów Municipality), the road network density shift index was negative.

5. The studies have shown that the development of the road network achieved through land consolidation is not always expressed by growth of the density index of the agricultural transport road and improving agricultural management conditions that are the primary goal of land consolidation does not always entail an increase in the number of roads in the designed area.

\section{References}

1. Crecentea R., Alvareza C., Frab U., Economic, social and environmental impact of land consolidation in Galicia. Elsevier, Land Use Policy, vol.19(2), 2002,pp. 135-147.

2. Markuszewska I., Farmland merging in Poland-A success or failure in land management policy. Journal of earth science and engineering, vol. 4, 2014, pp. 643-649.

3. Kupidura A, Łuczewski M, Home R, Kupidura P. Public perceptions of rural landscapes in land consolidation procedures in Poland. Land Use Policy, 2014, 39: pp. 313-319.

4. Kuang L., Ye Y., Zhao X., Guo X., Xie W., Evaluation on influence of land consolidation project on cultivated land quality based on agricultural land classification correction method. Transactions of the Chinese Society of Agricultural Engineering, Volume 32, Number 17, 1 September 2016, pp. 198-205(8).

5. Moravcoca J., Koupilova M., Pavlicek T., Pecenka J., Analysis of land consolidation projects and their impact on land use change, landscape structure, and agricultural land resource protection: case studies of Pilsen-South and Pilsen-North (Czech Republic). Landscape and Ecological Engineering, vol. 13, 2017, pp. 1-13.

6. Liqiang M., Zhongcai L., The status and developing trend of land consolidation in China and abroad. M \& D FORUM , pp. 392-396.

7. Vitikainen A., An Overview of Land Consolidation in Europe. Nordic Journal of Surveying and Real Estate Research., vol. 1, 2004, pp. 25-44.

8. Tomić H., Roić M., MastelićIvić S., Micević B., Jurakić G. Use of Multi-Criteria Analysis for the Ranking of Land Consolidation Areas. Conference: Symposium on Land Consolidation, At Apeldoorn, Netherland, 2016. 
9. Pijanowski J.M., Land consolidation development - discussion of a new approach recommended for Poland. Geomatics, Landmanagement and Landscape, no. 2, 2014, pp. 53-64.

10. Harasimowicz S., Ocena i organizacja terytorium gospodarstwa rolnego. Wydawnictwo Akademii Rolniczej w Krakowie. 2002.

11. Noga K. Efektywność ekonomiczna scalania gruntów. [w:] Woch F. (red.) Kompleksowe scalanie gruntów rolnych i leśnych oraz jego wpływ na środowisko. Materiały szkoleniowe nr 93, IUNGPIB, Puławy, 2006, pp. 124-142.

12. Woch F., Organizacja przestrzenna gospodarstw rolniczych oraz jej wpływ na efektywność gosodarowani. [w:] Harasim A. (red.) Współczesne uwarunkowania organizacji produkcji w gospodarstwach roliczych. Studia I Raporty IUNG-PIB, z. 7, Puławy, 2007, pp. 207-237. 